\title{
Finnish Muslims' Journey from an Invisible Minority to Public Partnerships
}

\author{
TUOMAS MARTIKAINEN \\ Migration Institute of Finland
}

\begin{abstract}
The article discusses the historical growth and development of the Muslim population and its contemporary situation in Finland. Finland was annexed as a grand duchy by the Russian Empire in 1809, which led to the presence of Muslim military personnel on Finnish territory and later enabled the settlement of Tatar Muslims from central parts of Russia. These Tatars were for a long time the only organized Muslim community in Finland. They maintained their cultural and linguistic traditions, while being very much at home in their Finnish civic identity. During the 1980s and especially since the 1990s Finland has received many Muslim immigrants, including international students, spouses, refugees, and asylum seekers. The article addresses several complexities in Muslim organizations' ethnic, national, and sectarian varieties, and takes on board the change in official policies towards Muslims over the years. It also examines the media debates and public attitudes to Islam. The historical Tatar minority's role has in many respects been important for more recent Muslim immigrants, and though little remarked in public debate, remains very important in seeking a relationship between Islam and north-western Europe.
\end{abstract}

Keywords: Islam, Muslims, Finland, organizations, governance, media, public opinion

High levels of ethnic and religious diversity have never characterized Finland. Indeed, the opposite has been the case. This country of 5.5 million inhabitants has been considered in others' and no less its own self-imagination an ethnically homogenous society, with two particular features with which minority studies scholars tend to be familiar: a small population of indigenous Sámi people; and a well-treated Swedish-speaking minority. However, this is only 
part of the story, as is usually the case with similar national and international imaginaries. Although the perception of ethnic homogeneity is no mere reflection of nationalist thinking - both the Sámi and Swedish speakers are smaller minorities, not exceeding 290,000 individuals - Finland still has its own share of other ethnic and religious minorities. This plurality in Finland's population in the post-Cold War era has often led to pronounced discourses. A major part of this rediscovered interest concerns Islam and the historic presence of Muslims in the country over more than two centuries (Martikainen 2013).

The history of Islam in Finland is a story of two quite different origins. The first relates to the break in Finland's long shared history with Sweden in 1809, when the region was annexed as a grand duchy within the Tsarist Empire. Finland was until then an eastern province of Sweden, but its proximity to the newly built Russian capital, St Petersburg, made it an attractive target for control from the east. When the political transition was over, Russian multi-ethnic, and indeed multireligious, troops settled in several Finnish localities. Among them were individuals of a Muslim background. There is a Muslim cemetery dating from the early nineteenth century close to the Bomarsund Fortress. Although it is now in ruins, the cemetery is on the Åland Islands, between modern Finland and Sweden. The soldiers may have been sojourners of a kind, but a more stable presence of civilian settlers collectively came to be known as the Tatar Muslims, to whom we shall return in the next section (Leitzinger 2006). The arrival of the first Muslims in Finland was therefore a result of population movements across the nineteenth-century Russian Empire (Cwiklinski 2016, 2-4).

The second phase in the evolution of Islam in Finland is more recent. Although there were already smaller numbers of non-Tatar Muslims in post-Second World War Finland, including international students and the occasional spouse or professional, a more sizeable presence first emerged in the 1990s, when Finland began to accept UNHCR refugees from Muslimdominated areas of the Middle East at the same time as independent asylum seekers were arriving. This coincided with and was related to the end of the Cold War and the more general opening of Finland to international migration. The last quarter of a century has seen a generally rapid rise in the numbers of people of foreign origin in Finland. They have arrived for several reasons, including ethnic return migration from the territories of the former Soviet Union in the form of family reunions, and to work or study. A sizeable proportion of the new immigrants has been Muslim, and this new Islamic presence resembles several other western European societies. However, Finland's case is unusual, because it did not import foreign labour during the 1960s and 
1970s: the country itself was a major exporter of human resources, especially to Sweden. The second story of Islam in Finland therefore belongs to the global population movements of the post-Cold War era (Martikainen 2013).

This article presents an overview of the presence of Muslims in Finland from historical times to the present day. Special emphasis is paid to a discussion of how Muslim communities have established themselves, and how the Finnish state and public have related to them.

\section{The settlement of Tatar Muslims in Finland}

As already observed, Finland was annexed as a grand duchy of the Russian Empire in 1809, resulting in the arrival of Russian troops. Among them were Muslims, who were primarily Tatars and Bashkirs from the VolgaUral region. Although their exact number is unknown, it was in the tens or hundreds - and certainly not many. Muslim servicemen were stationed in different garrisons around the country. As early as 1836 there was a military imam at the Sveaborg Fortress next to Helsinki, from which he also served Muslim civilians. The religious centre for Finnish Muslims at the time was the Orenburg Muslim Spiritual Assembly, as it was for all Muslims in European Russia (Halén and Martikainen 2016).

While some of the Tatars were among the military, the formation of a Tatar civilian community is related to the arrival and later settlement of Tatar merchants in the 1870s, who were mainly Mishar Tatars from the province of Nizhny Novgorod. Most came from a few villages, and they were often related. These Tatars were mainly farmers, who operated as pedlars during the winter. Some had also peddled in St Petersburg before coming to Finland. They were more positively perceived in Finland than in Russia itself. Word spread, and a small-scale chain migration or migration network began to emerge. Initially, only men came, but families gradually accompanied them (Halén and Martikainen 2016, 89-91).

The basic railway network in Finland was built in the latter half of the nineteenth century, and the Tatars were among those who exploited the opportunity it afforded to settle around the grand duchy. Tatar commercial activities included the selling of textiles, carpets, and furs. The Tatars were able to accumulate wealth, and successive generations improved their overall societal standing (Halén and Martikainen 2016, 89-91). This migration of Tatars to Finland continued until the 1920s, but it eventually ceased because of stricter Soviet internal and international mobility rules. Between the 1930s and the 1970s there was very little contact between the old homeland and settlers 
in Finland. Relationships with the homeland were re-established in the 1970s, when Soviet policy allowed increased international mobility (Leitzinger 2006).

There were about 120 Tatar families in Finland in the 1930s, with an average of 5.5 members per household. They began to receive Finnish citizenship from 1920: by the Second World War about half the Tatars were Finnish citizens. Most of the remaining non-citizens were later granted citizenship (Leitzinger 2006, 213-215). Nearly 180 Tatars participated in one way or another in Finland's war efforts, and ten died in the war. Like many Finns today, the Tatars take great pride in their participation in these efforts, even publishing a register of Tatar war veterans (Suomen Islam-seurakunta 2006). After the Second World War some Finnish and Estonian Tatars migrated to Sweden, where they established the first Swedish Islamic society in Stockholm, thus becoming a pioneer Muslim community further west (Leitzinger 2006, 142; Ståhlberg and Svanberg 2016).

The Tatars have always been a very small minority, numbering under a thousand individuals. According to Antero Leitzinger (2016, 144-165) most lived in the main urban areas of Southern Finland and some in a few smaller municipalities. Individual Tatars, however, were found throughout the country. One of the smaller areas with a Tatar settlement was the municipality of Järvenpää, near Helsinki. During the war, the first - and thus far only - purpose-built mosque in Finland was erected there. It is a wooden structure and includes a minaret (see Image 1). Apparently, some Tatar prisoners of war helped in its construction, and the mosque was definitely in use in 1942 and later. There are also Tatar mosques in the cities of Helsinki, Kotka, Tampere, and Turku (Leitzinger 2008). The Helsinki mosque, or 'Islam House', is a five-storey building. The congregation uses two floors; the rest of the complex is rented for commercial and culinary purposes. It was built in 1960 with domestic and international funding (Suomen Islam-seurakunta 1975, 28-32).

The Tatars have two religious organizations, the Finlandiya Islam Cemaati - Suomen Islam-seurakunta ('The Islamic Congregation of Finland'), founded in 1925, and the Tampere İslam Mahallest - Tampereen islamilainen seurakunta ('The Islamic Congregation of Tampere'), founded in 1943 (Leitzinger 1996, 166-167; Baibulat 2004; Leitzinger 2006, 155, 172). Tatars residing in other localities are members of one of these congregations. The Tatar religious organizations have a total of some 600 members, but their membership is ageing and has gradually shrunk, as shown in Figures 1 and 2. The Tatars also have several cultural and other associations for different purposes. Tatars have been active in publishing religious and cultural 


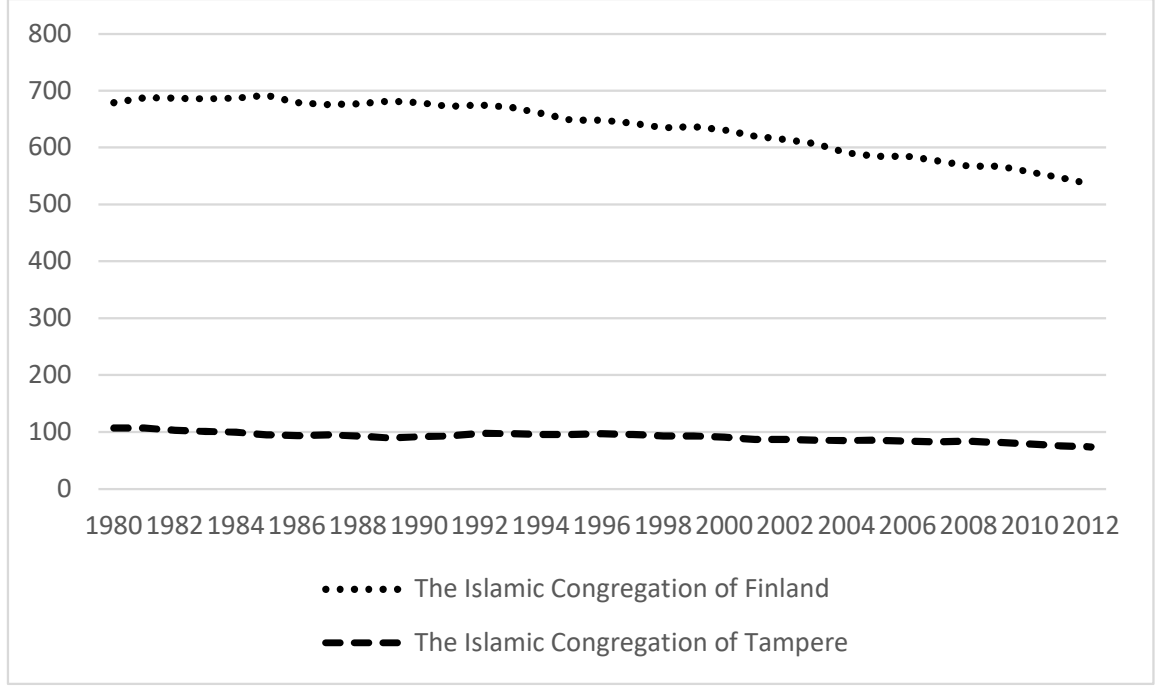

Figure 1: Membership of the Islamic Congregation of Finland and the Islamic Congregation of Tampere 1980-2012. Source: Statistics Finland.

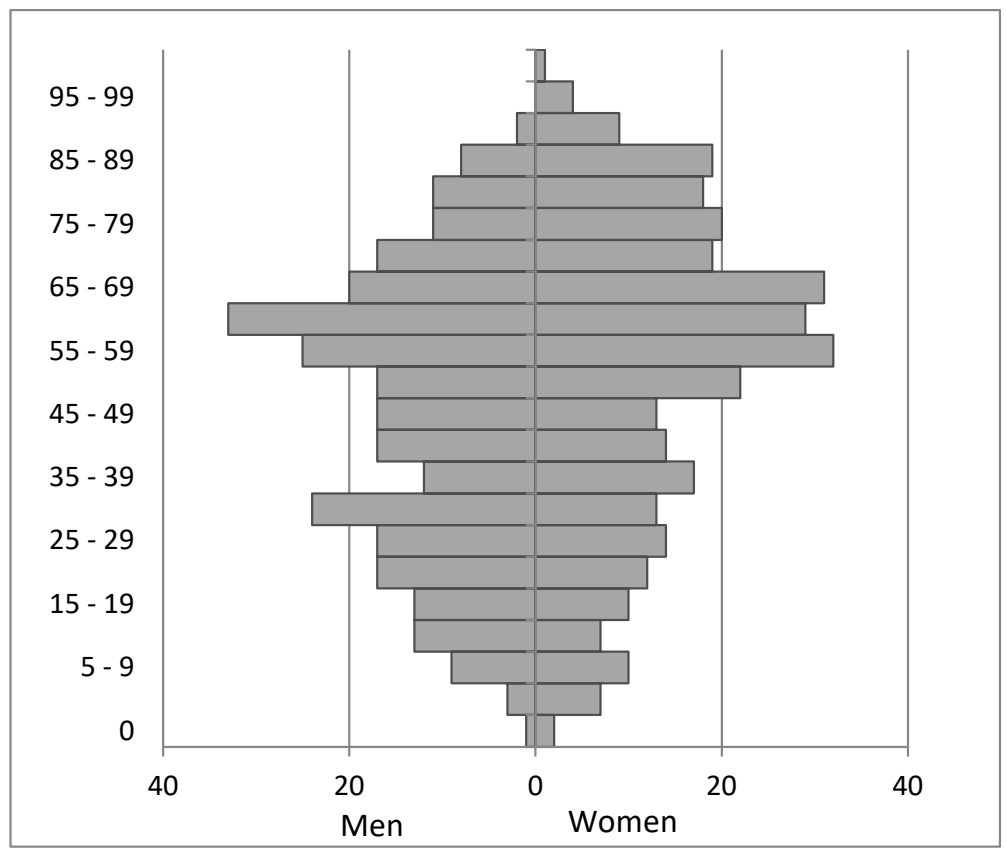

Figure 2: Source: Statistics Finland. 
literature, and most still speak their own language at ethnic meetings. Such multilingualism is certainly unique given the historic nature of the Tatar diaspora, which has become more or less linguistically assimilated into the Russian-speaking population in the Baltic countries (Cwiklinski 2016, 12). Their community newspaper Mähalla Habärläre ('News from the Community') is published in Tatar. However, for official and commercial purposes the community largely uses Finnish, turning to Tatar only for religious and cultural celebrations. Between 1948 and 1969 the Tatars had their own publicly recognized primary school (Leitzinger 2006, 235). They have prefered a low public profile, only seldomly taking an active role in presenting Islam in Finland, However, they have experienced it as a solidifying factor in their own communal cohesion. For example, the Tatars have only recently opened a basic website, to be found at tatar.fi. They are, however, respected and sought-after partners in Finnish public administration in activities dealing with Islam and interreligious relations, for example (e.g. Martikainen 2015, 128).

One of the main internal debates among Tatars concerns their identity (Sakaranaho 2002). Although most Tatars' origins lie in a few villages, and they are related to each other, finding a self-identification that suits everyone remains an ongoing effort. Antero Leitzinger (2006, 224-258) has described this in detail, and apart from the espousal of Sunni Islam, language has been the main factor and even a driver in this identity formation. As the Tatar language is related to Turkish, literary, cultural, and religious influences have been sought from Turkey. During the 1930s some Tatars were inspired by Kemal Atatürk's modernization and founded Turkish associations in Finland. This interest endured until the 1970s, when it became possible to visit the ancestral homeland and the Republic of Tatarstan. Although most Finnish Tatars do not originate from Tatarstan, it remains a source of inspiration through which contemporary Tatar ethno-nationalism has found its way into Finland. Even their relationship with newly arrived Muslims influences Tatar identification: they now emphasize their own ethnic (Tatar), linguistic (Mishar Tatar), and religious (Islam) identity as a unique (hence exclusive) blend, while simultaneously defining themselves within a historical cultural minority position in Finland and as Finns (Sakaranaho 2002). Finnish Tatars distance themselves from radical and Jihadist interpretations of Islam. They do not consider it part of their heritage, which is largely influenced by Sufi views and practices. Shifting ethno-religious identifications can also be found among other religious minorities in Finland. The historical Orthodox Christian minority is a case in point, as they have also sought different 
external points of identification based on the prevailing political situation (see Martikainen and Laitila 2014).

During the 150-year history of civilian Tatars in Finland the community has integrated well into Finnish society. Internally, its great challenge is its ageing membership, but the Tatars have been able to cope with this thus far. They are simultaneously affected by developments elsewhere in society and throughout the world. The rise of Islam in public consciousness over the last two decades has created closer contacts with the Finnish political administration, which has often asked the Tatars to function as middlemen between new Muslim immigrants and public administration (e.g., Martikainen 2019). They have therefore moved from the margins of society to a recognized and respected place at the centre in the eyes of the Finnish State.

\section{New Muslims of the post-Cold War era}

The Tatars were the only organized Muslim community in Finland for a long time, although Muslim individuals from many countries found their way to Finland (Sakaranaho 2006, 255-256; Leitzinger 2008). Other Muslims could participate in religious gatherings at the Tatar mosques, but they were not allowed to become members of the community itself. Linguistic difficulties hindered such participation, because Tatar was the main language used for religious and cultural activities, including the Friday sermon. During the 1980s, and especially since the 1990s, Finland has received many immigrants with a Muslim background as international students, spouses, refugees, and asylum seekers. This has led to a rapid growth in the Muslims population, which was an estimated 70,000 in 2015. This estimate is a matter of debate, but is an indication of the number. Higher numbers can be suggested, especially if the descendants of Muslim immigrants are considered. The difficulty with such estimates stems from the fact that a person is registered as an adherent of a particular religion in Finland if they join an existing religious association as a registered member. Such membership is much lower among immigrants, and Muslims are no exception (Martikainen 2011; Pauha 2017, 248-249). Moreover, because of other national registration practices, many Muslims resident in Finland have yet to be included in national statistics. For example, the 2015 influx of 32,500 people of mainly Muslim background including asylum seekers from the Middle East reaching Finland are not be included in these figures, but it is anticipated that at least 10,000 individuals will be granted the right to stay in the country. Most are from Iraqi and Syrian backgrounds (Jauhiainen 2017). 


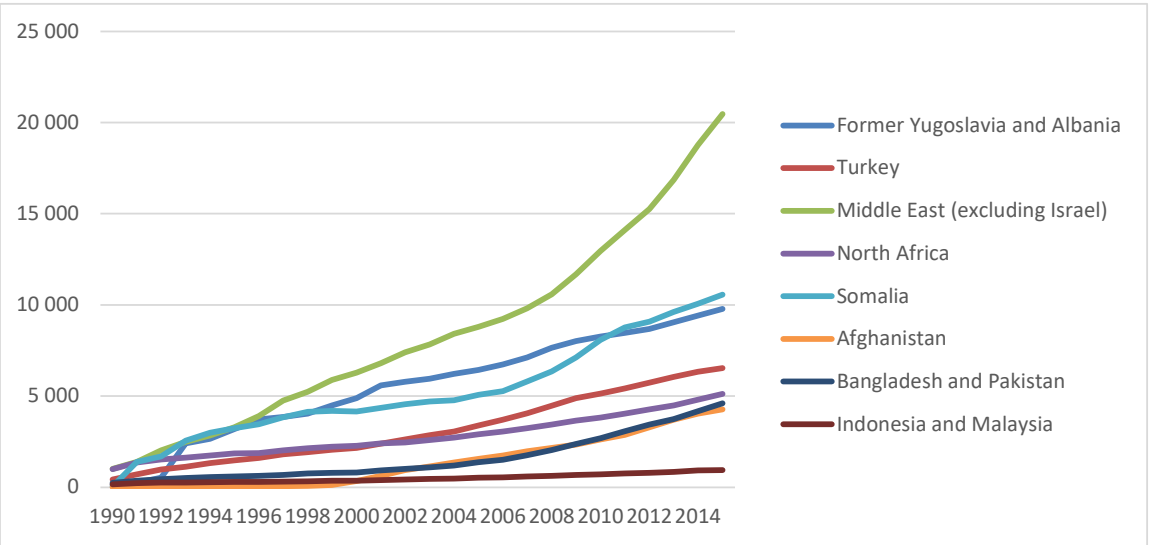

Figure 3: Immigrants from selected Muslim-majority countries and regions in Finland, 1990-2015. Source: Statistics Finland, Population structure, Country of birth according to age and sex by region 1990-2015.

The new immigrants are of diverse national and ethnic backgrounds from around the Muslim world. Figure 3 illustrates the diversity of the regional origin of immigrants from Muslim majority countries in Finland. The largest group consists of immigrants from the Middle East, especially from Iraq and Iran. The next are Somalis and people from the Balkans. They are followed by people born in Turkey, North Africa, the Indian subcontinent, and Southeast Asia. Among them are also non-Muslims, but the religious background of the majority is Muslim. Muslims from the former Soviet space are not included in the figure, because they are a minority among these immigrants (see Martikainen 2011). In any case, it is obvious that Muslims in Finland are a very heterogeneous group.

Labour immigration, which is a typical factor in Muslim immigration in many western European countries, has rarely been involved in Finland. The only characteristic common to a majority of Finnish Muslims is their refugee background, especially among Middle Eastern, Somali, Afghan, and former Yugoslav groups. Among the other main groups, including Turks and Southeast Asians, we find mainly marital partners and student migrants, and only some refugees. The dominance of international protection as a reason for immigration among Muslims has significant consequences for the population with a Muslim background. They are overrepresented among the lower income classes, so their financial situation in Finland is generally unstable. The Muslim population is highly concentrated in major 
urban areas, although somewhat different settlement patterns exist between different national and ethnic groups. For example, Turks are more dispersed than Somalis, who are strongly concentrated in Helsinki's metropolitan area (Martikainen 2013; Pauha 2017).

The second generation of the post-1990 Muslim immigrants is still mainly comprised of children and adolescents, but is becoming increasingly visible. The higher than average birth rate of many Muslim groups - for example, Somalis and Iraqis - in larger Muslim settlements means they are well represented in their age groups, and their particular needs have already been taken into consideration (Tirri, Rissanen, and Kuusisto 2016), For example, in the Finnish school system it is possible to receive teaching in one's own religion, and Islam is taught in many schools around the country (Sakaranaho and Martikainen 2015). Signs of young Muslims' identity politics are becoming visible as particular individuals are raising concerns that differ from those of the first generation (Pauha 2015).

The new Muslim population of Finland is highly diverse, mainly urban, and young in its age structure. It is less socioeconomically advantaged compared with the majority population, and it remains to be seen how the second generation can bridge the gap with the rest of the population. It is also estimated that the Muslim share of the population will continue to grow from the current 1.3 per cent to 3.4 per cent in 2050 (Pew Research Center 2015, 50). Over the last thirty years, new Muslims have been able to create an extensive religious infrastructure of mosques, associations, and other operations that support their religious identities and cultural activities.

\section{The Finnish state and Muslim organizations}

During the Russian era Islam was not an officially recognized religion in Finland, because Swedish laws and regulations were still largely in force in the grand duchy. The Lutheran church was a state church, and its members enjoyed a privileged position. The Tatars' religious activities were initially organized in private homes, and the formal organizational process took a long time. The first Muslim charity association was founded in 1915 in Helsinki, and a congregation in Terijoki ${ }^{1}$ in 1916, but the latter dissolved only two years later (Leitzinger 1996, 159-160; Leitzinger 2006, 166-167). After Finland's independence in 1917 legislation governing religion was liberalized. The Freedom of Religion Act of 1923 made it possible for Mus-

1 Terijoki is now known as Zelenogorsk and has been part of Russia since 1944. 
lims and non-Protestant Christians to register as state-recognized religious organizations (Heikkilä, Knuutila, and Scheinin 2005).

The Mohammedan (later Islamic) Congregation of Finland was founded under Finnish law in 1925, and its sister community in Tampere in 1943 (Leitzinger 2006). These were the only Islamic organizations in Finland until the mid-1980s, when the slowly growing non-Tatar Muslim community, consisting of Arabs in particular, began to organize on its own. The Islamic Society of Finland (Suomen Islamilainen Yhdyskunta) was registered in 1987 as the first non-Tatar community. It remains one of the largest and most active Muslim organizations in Finland. Dozens of new Islamic organizations have been founded as increasing numbers of Muslims have settled, with a growing presence around the country since the 1990s. The Islamic Society of Finland has played an important role in the process and has tried systematically at least to support the founding of new mosque associations both in the capital region and elsewhere in the country (Sakaranaho 2006).

According to Teemu Pauha (2017, 245-250) there were 129 registered associations in Finland that were probably Islamic in 2015. Among them were some eighty mosque communities, of which about thirty were in the Helsinki capital region. This suggests Finnish Muslims have a diverse and nationwide religious infrastructure that provides basic religious and ancillary activities to the growing Muslim presence in Finland. The Islamic field is very varied, although the Islamic Society of Finland aspires to become a nationwide central organizer of Islamic activities. Despite the general rhetoric that all Muslims share similar concerns and interests, there are many particularities in the profile and emphasis of Islamic organizations.

The officially recognized Muslim religious community organizations (rekisteröity uskonnollinen yhdyskunta in Finnish) had 13,300 members in 2015, as Figure 4 shows. This has risen from 1,200 in 2000, but it is important to note that a large number of Muslims do not officially belong to these organizations. This peculiarity of the Finnish statistics may be confusing, but official non-membership is common among immigrants and less so among the native population, meaning they are underrepresented in national religious statistics (Martikainen 2011). Nevertheless, the statistical increase indicates the growing numbers of Muslims and a growing tendency to become registered members.

In the initial organizational phase of Muslim activities in a new locality we find significant ethnic diversity among members of Muslim societies. However, as the Muslim community grows, it tends to splinter along ethnoreligious lines, although some multi-ethnic communities persist. The basic 


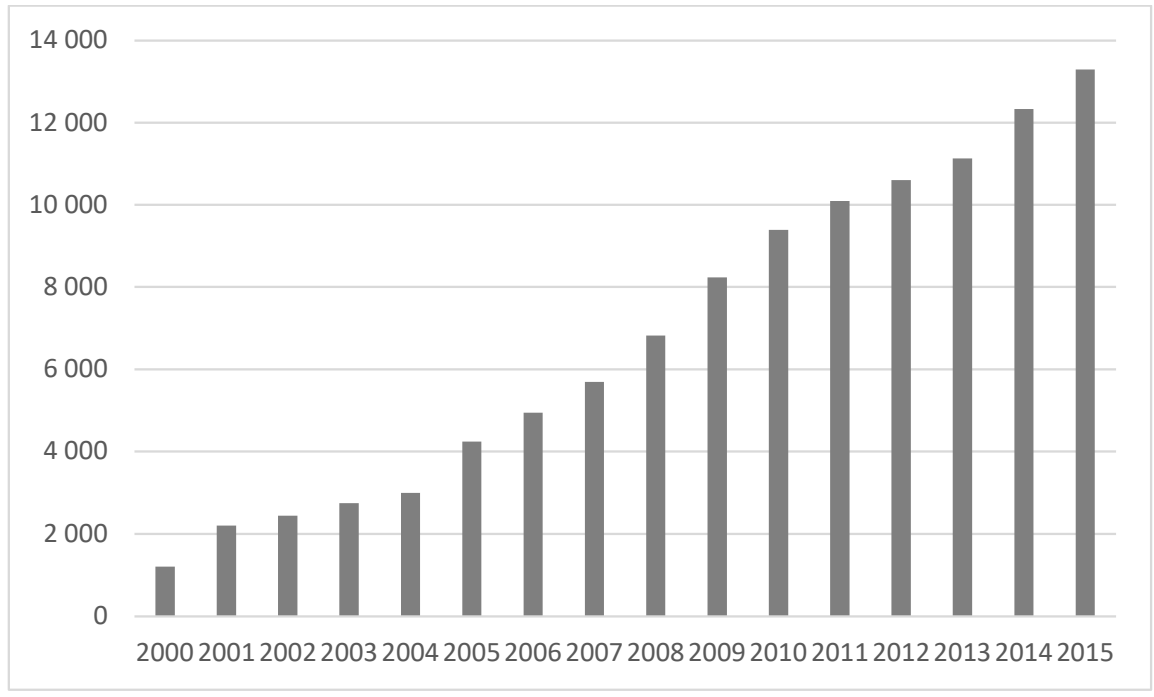

Figure 4: Registered members in recognized Islamic organizations, 2000-2015. Source: Statistics Finland, Population Structure, Population by religious community, age, and sex, 2000-2015.

division runs between Sunnis and Shias, who work together exceptionally in more practical issues. The Finnish Shia population consists of Iraqis, Afghans, and Iranians. The second main line of division is ethno-national. This is more prominent among Sunnis, because they are a more diverse group to begin with. Among them we find a significant share of mosque communities divided along ethno-national lines. For example, there are mosques numerically dominated by Somalis, Arabs, Kurds, Pakistanis, Turks, and Bosnians in the larger Muslim settlement cities. The third line of division is based on particular theological preferences and often relates to sympathy towards or membership of an Islamic movement. For example, the Tablighi Jamaat is known to be influential in some mosques. A more detailed academic understanding of the internal diversity of Finnish Muslim organizations has yet to emerge, but there are groups related in different ways to the Salafi/Wahhabi movements, the Muslim Brotherhood, the Diyanet, and various Shia movements. Beside these groups and influences, we find splinter groups that essentially relate to the personal relations of Muslim activists, a feature that is common among many other religious - immigrant and non-migrant - communities (Martikainen 2013).

In addition to local Muslim mosques and other associations a national representative body, the Islamic Council of Finland (SINE, Suomen Islami- 
lainen Neuvosto), exists. SINE was founded in 2006 with significant help from the Ombudsman for Minorities. The Council received state funding from the outset, which allowed it to focus on its core activities instead of expending its effort in fundraising, which is a common feature of migrant organizations' activities. Although SINE has become an important organization from the perspective of the Finnish public administration, it has not developed fully into an all-inclusive representative organization. However, some of SINE's key individuals belong to various networks that aim to enhance interreligious relations in Finland (Martikainen 2007, 2019).

Interreligious relations have gradually become an important staterecognized activity for enhancing societal peace. Interreligious activity was still a grassroots movement in the 1990s and early 2000s, but has now attained a higher profile. The key motivation for the Finnish state's interest lies in the terrorist attacks in New York and Washington on 9 September 2011, the Cartoon Controversy in 2006, and the many Islamist terrorist attacks in Europe over the last decade. In this context interreligious activity is seen as playing an essential role in upholding good ethnic and religious relations in the country. The National Forum for Cooperation of Religions in Finland (CORE) is a representative organization that brings together the 'Abrahamic' religions - Christianity, Islam, and Judaism. Its main task is to provide a common voice for these historic religions. Its foundation goes back to President Tarja Halonen's desire to improve interreligious relations in Finland. However, the organization was founded ten years later. Several other initiatives and NGOs work in the field (Martikainen 2016). At least in the cities of Turku and Helsinki local Muslim organization-public authority networks have also been established.

The growth of the Muslim population in Finland has led to several mutually reinforcing developments. First, Muslims now have an extensive and increasingly professional national network of Islamic societies and associations. Second, many of these Muslim organizations are increasingly considered in both local and national decision making, which has completely changed the previously peripheral role minority religious organizations played. For example, Turku has created a committee that focuses on fostering relations with local Muslim associations. Third, interreligious relations are seen as an important way to improve societal relations and prevent unwanted social phenomena such as radicalization. Although the authorities' interest is largely based on countering terrorism and radicalization, the connections have broader repercussions, changing historic state-religion relations and bringing minority religious issues to fore. Previously, 
the Finnish state has largely maintained active relations with the majority Evangelical Lutheran church, but much smaller religious organizations are now becoming serious negotiation partners (Martikainen 2016).

\section{Public image and opinions on Islam}

Islam and Muslims were long a distant and marginal topic in Finland. Despite the Tatar presence, Islam was not seen as native to Finland, and when it was discussed in public, it was in the context of foreign news and issues. Knowledge of the Tatar presence was poor; knowledge of Islam as a Finnish phenomenon was almost non-existent. This has changed over the years, with Islam increasingly being seen as a Finnish issue.

Teemu Taira has studied the image of Islam in the main Finnish newspaper, Helsingin Sanomat, between 1946 and 1994. He has identified four phases in the debate about Islam. First, Islam, or 'Mohammedanism' (muhamettilaisuus in Finnish) as it was then called, was seen as a backward religion. Islam began to come to the fore in the early 1960s in relation to political developments such as the Algerian War, when it was seen as a socially cohesive force for people's nationalist aspirations. Second, this nationalist phase was reimagined in the late 1960s in the light of Soviet and US interests that squeezed Islam between capitalism and communism. Islam was viewed as a passive player in the battles between the great powers. Regionally, the imaginary was still largely concerned with the MENA region. Third, with the rise of political Islam and the establishment of the Islamic Republic in Iran, Islam began to appear as an independent force. The developments in Iran were viewed with horror, but Islam as a religion was gradually seen as compatible with modern society (Taira 2008, 202-206).

Fourth, the presence of Muslim minorities in European countries slowly emerged as a topic during the 1980s. The Satanic Verses controversy was much debated in the Finnish media from 1988. As greater numbers of Muslims arrived in Finland during the 1990s, Islam was gradually seen as a phenomenon more closely related to Finland. Although Islam was generally not a key element in the presentation of immigrants with a Muslim background, who were more often described in national or ethnic terms, Islam was now no longer seen as merely something somewhere far away. The political crises that led to asylum seekers arriving in Finland in the early 1990s, including the breakdown of Somalia and the wars following the dissolution of Yugoslavia, received much attention, gradually leading to a growing recognition of Islam as something present in Finland too (Taira 2006, 206-208). 
The media researchers Pentti Raittila and Mari Maasilta (2008) have compared media debates on Islam in 1987, 1997, and 2007 that supplement Taira's findings. Their analysis confirms that Islam is represented in media debates mainly in political contexts. This means it is seldom examined in cultural or religious frameworks, but as part of other developments. Over the twenty-year period the study examines, Islam is increasingly presented as something present in the Nordic countries (Denmark, Finland, Norway, and Sweden), meaning that almost a quarter of media mentions situate Islam in the region. This figure was about a tenth at the start of the period. Nevertheless, mentions of Islam are situated mainly in non-European territories. Moreover, issues related to political violence are dominant during the entire period, creating a somewhat one-sided image of Islam, although the journalism as such is unsensational and of good quality. While no systematic overview of Islam in the media has been produced since the above studies, it seems likely that the overall picture has remained the same. Islam is often presented in a problematic light, and associated with political violence and terrorism.

Finnish public opinion on different religions, including Islam, has been surveyed since 1989. Islam has been viewed consistently in a very negative light, and the attitudes to it have remained quite stable. About half the population has great reservations about the religion, and only a small percentage views it positively. Other religions Finns view quite critically include the Jehovah's Witnesses and Mormons. The main difference compared with other world religions with a minor presence in Finland (Buddhism, Catholic and Orthodox Christianity, Hinduism, Judaism) is that over the same period they have gradually come to be viewed more positively. Kimmo Ketola suggests that a feature uniting those religions viewed by Finns especially negatively may be that they are seen to cross the line between personal devotion and the public visibility of religion. The former is seen as non-problematic, and the latter as much less acceptable (Ketola 2010, 45-46).

Kimmo Ketola and Teemu Pauha have analysed Finnish attitudes to Islam, which they suggest are exceptionally critical even by international comparison. Based on the 2011 Gallup Ecclesiastica poll, 6 per cent of Finns viewed Islam positively, 33 percent neutrally, and 50 percent negatively, while 11 percent had no opinion. Ketola's and Pauha's analysis identifies more prominent criticisms that reflect right-wing political preferences, patriotism, and a worldview that emphasizes differences between population groups. Strong religiosity also manifests views critical of Islam, but they are absent from moderate mainstream religiosity (Pauha and Ketola 2015, 100). 
The negative media image and public attitudes to Islam contrast strongly with the more accepting administrative responses. A planned multi-millioneuro grand mosque and dialogue centre in Helsinki provides a telling example of the same dynamic. The administrative planning processes ran quite smoothly, but political and public views were far more critical (Pauha and Martikainen 2017). The plan was eventually withdrawn because of political rather than administrative or planning issues. However, it should be remembered in the current debates about Islamophobia that negative Finnish attitudes to Islam have been very stable. Not even the growth of the Muslim community in Finland has markedly changed overall attitudes. It is therefore likely that whatever lies behind the attitudes, they are related to broader cultural values than an Islamophobia perspective would suggest.

Finally, one aspect that may over time influence these public attitudes is the growth of the anti-Islamic rhetoric and agenda in the Finnish political system since the mid-2000s. A social movement known as the 'immigration critics' (maahanmuuttokriittisyys in Finnish) emerged in the blogosphere and on social media in the early 2000s. Over time, it found a political home in the Finns Party (also known as the 'True Finns'; Perussuomalaiset in Finnish) and has won significant political victories in several elections since 2008. Their relationship with Islam shares many of the premises of the proponents of Eurabia: that Islam is a threat to Europe, and Muslims aim to conquer the continent by various means (Carr 2006). These ideas are blended with a general critique of humanitarian immigration and are associated with a dystopian view of European cultural weakness. Although they are not completely dominant even in the Finns Party, it seems likely they have also begun to influence broader political thought.

\section{Conclusion}

Finland provides an interesting case study of Muslims in Europe, as it has both a historical Muslim minority and Muslims who have arrived more recently, but almost no labour migrants from the 1960s and 1970s. The Tatar Muslims of the nineteenth century were able to organize themselves effectively with little societal attention and remained invisible to the broader society. The new Muslim presence has benefited from the Tatar presence, because organizing Islamic societies in Finland has generally been easy, and the formal acceptance of Islam has therefore been unproblematic. This contrasts significantly with many Finns' very negative view of Islam, and it remains to be seen how increasingly anti-Islamic political rhetoric will influence the situation. 
The Tatars and new Muslims maintain contacts, but their main concerns are quite different. The Tatars have a good infrastructure to support their traditions. They know how Finnish society works and benefit from good societal connections that support their cause. New Muslims are still creating a space for themselves, and have much to learn about Finnish society and how to promote their interests within it. New Muslims are a very heterogeneous group, and in many cases it would be difficult for them to work for a common cause. The main issue that unites most Muslim groups in contemporary Finland is the pervasive negative image of Islam. This is the most common complaint of all Muslim groups and individuals.

The Finnish State's engagement with Muslim organizations is also noteworthy. They have supported them by including Muslims in discussions about contributing to societal peace and improving interreligious relations. This suggests we are seeing the operation of a new model of the relationship between the state and religion, in which minority religions are actively included, and which was not the case before the 2000s. Muslim organizations have emerged from the margins of society to take a more prominent place in an evolving Finnish society. Much of this has happened because of external developments in Europe, and less because of actual events in Finland. We may therefore assume that Islam's future trajectories in Finland will be elementarily affected by affairs elsewhere - and therefore unpredictably.

$$
* * *
$$

TUOMAS MARTIKAINEN is the Director of Migration Institute of Finland. E-mail: tuomas.martikainen@migrationinstitute.fi

References

\section{Baibulat, Muazzez}

2004 Tampereen Islamilainen Seurakunta: juuret ja historia. Tampere: Tampereen Islamilainen Seurakunta.

\section{Cwiklinski, Sebastian}

2016 Introduction - Ingvar Svanberg and David Westerlund (eds), Muslim Tatar Minorities in the Baltic Sea Region, 1-18. Leiden: Brill. 
Carr, Matt

2006 You are now entering Eurabia. Race E Class 48(1), 1-22.

Halén, Harry and Tuomas Martikainen

2016 Finland - Ingvar Svanberg and David Westerlund (eds), Muslim Tatar Minorities in the Baltic Sea Region, 86-104. Leiden: Brill.

Heikkilä, Markku, Jyrki Knuutila, and Martin Scheinin

2005 State and Church in Finland - Gerhard Robbers (ed.), State and Church in the European Union, Second Edition, 519-536. Baden-Baden: Nomos.

Jauhiainen, Jussi

2017 Johdanto ja johtopäätökset. In: Jussi Jauhiainen (ed.), Turvapaikka Suomesta? Vuoden 2015 turvapaikanhakijat ja turvapaikkaprosessi Suomessa, 5-18. Turku: University of Turku, Department of Geography and Geology.

\section{Ketola, Kimmo}

2010 Uskontotilanteen muutos ja suomalaisten suhtautuminen eri uskontoihin - Tuomas Martikainen and Ville Jalovaara (eds), Uskonnon ylösnousemus: Kirkon, uskonnon ja kulttuurin murros, 40-51. Helsinki: Magma.

\section{Leitzinger, Antero}

1996 Mishäärit-Suomen vanha islamilainen yhteisö. Helsinki: Kirja-Leitzinger 2006 Suomen tataarit: Vuosina 1868-1944 muodostuneen muslimiyhteisön menestystarina. Helsinki: East-West Books.

2008 Marginaalimuslimit - Tuomas Martikainen, Tuula Sakaranaho, and Marko Juntunen (eds), Islam Suomessa: Muslimit arjessa, mediassa ja yhteiskunnassa, 85-110. Helsinki: Suomalaisen Kirjallisuuden Seura, 2008.

\section{Martikainen, Tuomas}

2007 The Governance of Islam in Finland. Temenos 43 (2), 243-265.

2011 Maahanmuuttajien uskonnollisen taustan tilastollinen arvioiminen Suomessa. Teologinen Aikakauskirja 116 (3), 232-246.

2013 Religion, Migration, Settlement: Reflections on Post-1990 Immigration to Finland. Leiden: Brill.

2015 Reconfiguring the Societal Place of Religion in Finland: Islamic Communities Move from the Margins to Partner in Civil Society - Jane Garnett and Sondra L. Hauser (eds), Religion in Diaspora: Cultures of Citizenship, 121-37. Basingstoke: Palgrave Macmillan.

2016 Managing Religious Diversity in Finland: From Church Law to Governance Networks - Andrew Dawson (ed.), The Politics and Practice of Religious Diversity: National Contexts, Global Issues, 118-32. London: Routledge.

2019 The Founding of the Islamic Council of Finland - Tuomas Martikainen, José Mapril, and Adil Khan (eds.), Muslims in the Margins of Europe. Leiden: Brill. 


\section{Martikainen, Tuomas and Teuvo Laitila}

2014 Population Movements and Orthodox Christianity in Finland: Dislocations, Resettlements and Identities - Maria Hämmerli and JeanFrançois Mayer (eds), Orthodox Identities in Western Europe: Migration, Settlement and Innovation, 151-178. Farnham: Ashgate.

Pauha, Teemu

2015 Ambassadors of Faith: Young Muslims Negotiating for Agency in the Face of Discursive Government. Journal of Religion in Europe 8 (1), 73-100.

2017 Finland - Oliver Scharbrodt, Samim Akgönül, Ahmet Alibašić, and Egdūnas Račius (eds), Yearbook of Muslims in Europe. Volume 8, 239-54. Leiden: Brill

\section{Pauha, Teemu and Kimmo Ketola}

2015 Mikä selittää suomalaisten islam-vastaisuuden? - Riku Hämäläinen and Heikki Pesonen (eds), Kohtaamisia: Kirjoituksia uskonnosta, arjesta ja monikulttuurisuudesta, 94-105. Helsinki: Helsingin yliopisto, Maailman kulttuurien laitos, Uskontotiede.

Pauha, Teemu and Tuomas Martikainen

2017 Lausunto Helsinkiin suunnitellusta moskeija- ja dialogikeskuksesta. Turku: Siirtolaisuusinstituutti.

\section{Pew Research Center}

2015 The Future of World Religions: Population Growth Projections, 2010-2050. Washington, DC: Pew Research Center.

\section{Raittila, Pentti and Mari Maasilta}

2008 Silmäyksiä islamin esittämiseen suomalaisessa - Tuomas Martikainen, Tuula Sakaranaho and Marko Juntunen (eds), Islam Suomessa: Muslimit arjessa, mediassa ja yhteiskunnassa, 225-43. Helsinki: Suomalaisen Kirjallisuuden Seura.

\section{Sakaranaho, Tuula}

2002 "Kansamme tuntematon kansanosa": Suomalaisten tataarimuslimien julkisuuskuva - Tuula Sakaranaho and Heikki Pesonen (eds), Uskonto, julkisuus ja muuttuva yhteiskunta, 132-159. Helsinki: Helsinki University Press.

2006 Religious Freedom, Multiculturalism, Islam: Cross-reading Finland and Ireland. Leiden: Brill.

\section{Sakaranaho, Tuula and Tuomas Martikainen}

2015 The Governance of Islam in Finland and Ireland. Journal of Religion in Europe 8 (1), 7-30.

\section{Ståhlberg, Sabira and Ingvar Svanberg}

2016 Sweden - Ingvar Svanberg and David Westerlund (eds), Muslim Tatar Minorities in the Baltic Sea Region, 145-58. Leiden: Brill. 


\section{Suomen Islam-seurakunta}

1975 Suomen Islam-seurakunta 1925-1975. Helsinki: Suomen Islam-seurakunta.

2006 Suomen Islam-seurakunnan veteraaniteos. Helsinki: Suomen Islamseurakunta.

\section{Taira, Teemu}

2008 Islamin muuttuva julkisuuskuva: Tapaustutkimus Helsingin Sanomista 1946-1994 - Tuomas Martikainen, Tuula Sakaranaho, and Marko Juntunen (eds), Islam Suomessa: Muslimit arjessa, mediassa ja yhteiskunnassa, 200-24. Helsinki: Suomalaisen Kirjallisuuden Seura.

\section{Tirri, Kirsi, Inkeri Rissanen, and Elina Kuusisto}

2016 Finnish Teachers and Diversity: The Case of Muslim Students - Donald K. Sharpes (ed.), Handbook on Comparative and International Studies in Education. Charlotte, NC: Information Age Publishing.

\section{Appendix.}

Image 1. The Järvenpää Tatar Mosque, built in the 1940s. Photo by the author.




